\title{
THE RELATION BETWEEN THE MIGRATION, POPULATION AGING, LABOR FORCE PRODUCTIVITY AND ECONOMIC GROWTH: AN ANALYSIS FOR BULGARIA
}

\author{
Venelin Terziev ${ }^{1^{\star}}$, Hamit Can $^{2}$ \\ ${ }^{1}$ Corresponding Member of the Russian Academy of Natural History, Moscow, Russia, Prof. \\ D.Sc.(Ec.), D.Sc. (National Security), Ph.D., National Military University, Veliko Tarnovo, Bulgaria; \\ University of Rousse, Rousse, Bulgaria, email: terziev@skmat.com; \\ ${ }^{2}$ Ph.D., Institute of Social Science, Namik Kemal University, Department of Economics, Namık \\ Kemal University, Tekirdağ, Turkey, e-mail: hamitcan88@hotmail.com. \\ ${ }^{*}$ Corresponding author
}

\begin{abstract}
In this study, the relationship between population, elderly population and economic growth is analyzed theoretically, taking into account the demographic change of the Bulgarian population and the more aging phenomenon. Thus, the change in the age structure of the Bulgarian population was investigated and the factors affecting the growth of the relationship between economic growth were investigated. Developed countries are trying to solve the problem of low population growth with migration. Developed countries with younger populations, such as the European Union, also allow dwellings in some periods to dampen the population and prevent the resulting loss of employment. According to a report published by the EU Statistical Institute (Eurostat), it is stated that the number of the population working in the European Union will decrease by an average of 50 million in 2060. When the current migration rate is taken into account, it is predicted that by 2060 the number of people working in European Union countries will be 110 million people less than today's number. Migration in the demographic development of the European Union has a great proposition. If a qualified migration flow is provided, it is foreseen that the deficiencies that will arise in the European Union employment market in the coming years will be eliminated.
\end{abstract}

In this study, attempts were made to determine the size of the changes taking place in the country's economy, depending on the livelihoods in Bulgaria.

Keywords: Migration and Aging Population, Economic Growth, Labor Productivity, Bulgaria.

\section{INTRODUCTION}

When the changes in past birth and death rates are examined, fertility rates are decreasing, life expectancy is increasing, and all of these causes the change of global age structure. "Population aging is due to a change in the age structure of a population, a decrease in the share of children and young people in that population, and an increasing share of elderly people (over 60 years or over 65 years). The global aging process is also called 'demographic transformation'. In this transformation, the proportion of the elderly population in the total population increases as the age group of the population changes in shape, the mortality and fertility decline, the expected life expectancy after birth increases and the proportion of children 
and young people in the population decreases.

In the study, the relation between population, elderly population, labor productivity and economic growth was studied theoretically by taking the example of Bulgaria according to different approaches. The features and strengths of this work that are different from the other works in the literature are as follows:

- Determination of the labor productivity and economic effects of the young population migration that occurred in the European Union as a result of the idea that the employment and salary facilities in the other European countries are better.

- As a result of immigration, 60 years of age and over in the country and the effects of the density of retired population on productivity and its economic growth.

- Pre-determination of the problems and economic crises that will occur in the country if the migration rate and the young population density continue in the same direction in Bulgaria.

- In order to further improve the status of the European Union and the world, what should be the measures, measures, strategies and investments Bulgaria should take in terms of economic, labor productivity, prosperity and technological development as a result of the increase in the population density of the young population, Determination of the targets in the subject

In line with the results obtained, it is aimed to develop strategies to ensure that the young population remains in the country and economic development is achieved effectively. The laws, sanctions and incentives that will be created in this direction can be a very important step in increasing the strategic position of the country in the world.

\section{LITERATURE REVIEW}

The recent aging of the population is one of the most important issues that many developed and developing countries are interested in (Bloom et al., 2011: 1). Population aging and demographic transformation at the global and national level, economic, social, demographic and so on. Causing various problems to occur.

The most important of the problems caused by the aging of the population is the change of labor supply. As the population changes in age composition, the population that cannot participate in economic activities and has no participation in the labor force is increasing and the labor supply is changing. As the number of people aged 60 years and over in the age structure of the population increases, the number of working age population is decreasing. The change in the age structure of the population affects the growth of the labor market and employment and the economic growth of the population, the aging of the population, the total labor force supply, the productivity of the old labor force, employment structure, wage income, savings, production and consumption. The age structure of the population is a very important external variable that affects economic growth. In addition to the effects of increased elderly population, labor market and economic growth, the impacts on health and social security systems are also very important (Bloom et al., 2008: 15-16; Bloom et al. The study of the effects of age change on economic growth in studies on the relationship between population aging and economic growth, exploits the lifetime income hypothesis. According to Modigliani and Brumberg's 1954 and 1980 studies of Ando and Modigliani's 1963 study of Lifetime Income Hypothesis, individuals' working and participating economic needs and saving vary according to their life span. While participation at young ages, consumption trends and savings are high, participation in the production of elderly products, and especially savings, falls considerably. People have a higher saving during their lifetime especially when their incomes are higher and when they participate in production. The reason for this is that they can continue their consumption in old age during their retirement periods when their income falls. This means that the total labor supply, productivity, income and per capita savings vary according to these trends as a result of the majority of individuals acting according to the lifetime income hypothesis. Total labor supply, productivity, income and per capita savings are important factors in determining economic growth. Especially the age group is big on labor supply and per capita savings. The labor supply and per capita savings of those aged 60 and over are lower than the labor supply and per capita savings of working adults. In this context, although there is no change in the productivity and income factors that are important in determining economic growth, slower growth is likely to occur due to the surplus of the elderly age group. This approach has been assessed in Bloom and Williamson's study of the effects of population aging on the rapid economic growth of East Asia in 1998, the second half of the 20th century. In the late 1940s, infant and child mortality decreased in these countries and therefore there was a decrease in fertility. As a result of death rates and reductions in fertility, a new generation of newborns has begun to emerge. When this generation reaches its working age, it has made significant increases in labor supply and saving. According to Bloom and Williamson (1998) and Bloom, Canning, and Malaney (2000), the miracle of growth in East Asia during 1965-1990 is explained by the actual demographic change (Bloom 
et al., 2008: pp. 1-38; Bloom et al. 2011: pp. 12-13; Deaton, 2000: pp. 1-46).

The decline in the age-old population that can work after the aging of the population causes the workforce in the economy to become a scarce factor of production. In countries with older populations, the number of working people entering the labor market is reduced, while the lower productivity due to the physical and mental wear of the older workforce reduces the total labor supply. Another consequence of population aging is that the increase in social security and tax cuts also has a different impact on the labor market. The increase in the elderly and dependent population increases the cost of financing pension benefits. This increasing burden is affecting the population working through the social security system. This means that the cost of labor increases. The increase in labor costs, which constitutes a major obstacle to employment, also reduces the tendency to work for the employer while reducing the tendency to work for the working population on the one hand. Compulsory interruptions of the social security system have an increasing effect on unemployment (Salin, 1996: pp. 25-26). Young people who have recently completed their education constitute a general human capital that can integrate technological innovations (Железаров, 2009; Железаров, 2005; Иванов, Железаров, 1998). However, despite the fact that the human capital of an employee who has worked for the same company over a long period has its own advantages, the transfer of this human capital from one place to another has been difficult and useless. At the same time, it is believed that the elderly are at the lowest productivity level in general for all employers (Santos, 2001). In addition, companies prefer young people to depreciate costs such as recruitment and training, assuming they will work longer than elderly people (Jolivet, 2001: pp. 65-82).

With the aging of the population, a number of possible developments are expected, especially in the developed countries, in relation to the banking sector. There is an expectation on the active sides of the banks that the demand for the loan will decrease with the decrease of the young population. Therefore, the volume of individual credits is expected to decrease. On the passive side of the banks, it may come into question that the tax incentives and subsidies required by the public for the creation of new saving instruments together with the aging population may come into question. Pension fund schemes have also been consolidated within the framework of more serious risk surveillance, particularly in the Netherlands, and in some other European countries. In addition, there is a need for efforts to make up for falling claims by other products for the elderly and retired population. It is anticipated that the evaluation of non-bank financial institutions such as insurance companies, pension funds and mutual funds will also increase the demand for such institutions (Groome et al., 2006, pp. 44-47). Due to these developments, it is expected that there will be a downward pressure on the demand for bank loans and deposits. In this way, banks will need to pursue more competitive policies in order for their growth to continue.

Prettner (2012) and Lee et al. (2011), but most of the literature in the literature suggests a negative relationship between population aging and economic growth (Narciso, 2010; Bloom et al., 2010, pp. 583-612; Lisenkova et al., 2012, pp. 12-13; Walder and Döring, 2012, pp. 63-80). Hock and Weil (2012); Walder and Döring (2012) argue that the increase in aging populations will cause a decline in consumption and growth will be hindered.

Auerbach et al. (1989) OECD members have identified the economic dynamics of population aging across the four countries. The result of the study is that national savings rates, real wage rates and demand deposits are highly sensitive to the old dependency rate. Barlow (1994) examined the relationship between population growth and economic growth. In the short term, the increase in fertility has a negative effect on the growth of per capita income; Whereas in the long run the direction of this effect changes positively. Because today's fertility rate is highly correlated with past fertility and population growth rate will be negative in the short term and positive in the long term. Bloom et al. (2011) The results of population aging have been analyzed for economic growth. For OECD countries, the prolongation of life expectancy, the downsizing of families, more savings for retirement, and increased participation rates in the female workforce will not be adversely affected by the aging of the economic growth population. However, in countries that are not members of the OECD, especially in developed countries, the labor force that can be employed due to the aging of the population is experienced and therefore the production will be adversely affected. Bloom et al. (2001) The relationship between economic growth and demographic transformation is examined in East Asia, Japan, OECD, North America, Eastern Europe, North Asia, Latin America, the Middle East and South Africa and Saharan countries. Changes in the age structure of the country have significant effects on the economic performance of the country. Countries with high rates of children allocating resources to child care from their national income cause pressure on the rate of economic growth. Conversely, if the density of working population of an country is too high, any additional production of this group will positively affect economic growth. Middle age and older age groups will have a large share, and a significant portion of the country's resources will be made available to the needs of those not in production. Bloom et al. (2006) examined the impact of demographic change on the social security system and savings. The results of 
macroeconomic panel data analysis show that post-retirement social security incentives increase the total savings in countries. However, in countries where social security is provided by intergenerational solidarity, this positive effect disappears. Bloom et al. (2009) examined the relationship between population aging and economic growth. Participation in the workforce will be reduced at this point, as a decrease in the fertility rate will lead to a decrease in the rate of young dependency but an increase in the rate of older dependency. In addition, the decrease in fertility will increase women's participation in the workforce, leading to a perceived increase in the proportion of the workforce to population. Boersch-Supon (2001) The effects of population aging on the saving behavior of individuals and their impact on the capital market have been examined. The aging of the population has led to the fact that the intergenerationalism in the social security system is more prevalent and that economies such as Germany, France and Italy, which have poor capital markets and poor capital performance, are more influential on capital markets. The younger generations in these countries are aware of the need to meet their retirement income needs with their own private savings. As a result, the aging of the population seriously changes the macroeconomic balance of Europe. Cutler (1990) examined the opportunities and changes that population aging can bring. Although demographic changes will create an increase in per capita income in the near future, unlike changes in capital intensity; while in the distant future there will be a decrease in per capita income. Deaton and Paxson (2000) investigated how demographic changes in the population will affect future saving trends, particularly in the Taiwan country. It has been found that the change in demographic structure of the population is an individual result, not a generality of the nation, but an increase in saving. Accordingly, young people in Taiwan are accumulating more for the future than what their parents did when they were at their age. For this reason, there is no direct relationship between age and saving rate. Fogel (1994) identified economic growth and assessed the impacts on population rates. Population forecasting, national income measurement, leisure time requirements, pension policies and the demand for health services are the result of economic growth theory. Harris et al. (2001) The impact of population aging on public education expenditures has been examined. According to the estimated results of the model, the aging of the population has a negative effect on the education expenditures. The increase in the share of aging in the nation puts pressure on education expenditures. Higgins (1998) examined the relationships between age distributions, national savings and current account balance. According to panel data analysis results using time series data for 100 countries, the increase in the dependency ratio of young people and the elderly is associated with low saving rates. For this reason, demographic changes are effective in determining the current account balance. Kelley and Schmidt (1996) investigated the impact of population growth on economic growth. According to comparative country analyzes, the direction of the effect of population aging on economic growth is negative in the 1980s; The influence in the 1960s and 1970s is meaningless. Lee and Mason (2010) examined the relationship between fertility, human capital and economic growth in the demographic transformation process. Increasing human capital investments with decreasing fertility rates initially reduce consumption with a decline in fertility rate, but aging of the population and transfer payments made by the elderly increase consumption. Lefebvre (2006) analyzed the effect of population aging on consumer demand in Belgium. Because consumption expenditures vary throughout life, the structure of total consumption varies with the age of the population. Increased health, shelter and leisure spending with aging; Clothing, equipment and transport expenditures. Leibfritz et al. (1995) Analyzed the impact of demographic changes on public and national savings. Changes in the demographic structure can only be achieved by improvements in the financial structure of the countries. For this reason, the increase in retirement age is still a matter of debate as it will make a major contribution to the social insurance system. Zweifel et al. (2004) examined the effect of population aging on health expenditures. By examining the health expenditures of the deceased people, it is concluded that the age of health expenditures is insignificant. For this reason, the aging of the population will not have a significant impact on future health expenditures. Fougere and Merette (1991) investigated the effects of population aging on economic growth in seven industrialized countries of the United Kingdom, France, Italy, Sweden, Japan, Canada and the United States. The OLG model of Hviding and Merette (1998) was used in the general equilibrium model together with the theory of internal growth. Population aging causes significant changes in economic growth in the long run. Aging can provide many opportunities for future generations. Investments in human capital, especially made for future generations, significantly reduce the negative effect of aging on per capita output. Prettner (2009) The effect of population aging on economic growth in the long run has been examined. Romer (1990) and Jones (1995) model was used as the internal growth model. The increase in lifetime has a positive effect on the increase in per capita output in the long run. Futugami and Nakajima (2001) The effect of population aging on economic growth has been examined. With the theory of internal growth, the lifetime savings model in the general equilibrium theory is used. Population aging is not a factor that negatively affects economic growth. In addition, the effects of postponing retirement policies have been examined and these policies have been achieved as a result of slowing growth. Bloom et al. (2003) investigated the lifetime savings and working life of the length of life along with changes in the age structure of the population. The time series has been used and the increase over the lifetime increases the saving 
rates. But even in the case of a constant population growth, the prolongation of the life span compensates for the saving rates due to the increase in the old age dependency ratio. Life span increases average saving rates.

However, when the age structure reaches equilibrium, these increases are beginning to decrease(The European Commission's research on aging in 2012 on the impact of public spending has indicated that a significant reduction in the labor supply is expected when the demographic transition comes to $2050.30 \%$ in Italy and $17 \%$ in Germany (Economic Policy Committee and European Commission, 2006). These results indicate that migration figures may or may not increase for closure of employment openness.

\section{REFERENCE LIST}

Auerbach, J. Alan ve Kotlikoff, Laurence - Hagemann Robert ve Nicoletti, Giuseppe (1989), „The Dynamics of an Aging Population: The Case of Four OECD Countries", National Bureau of Economic Research, Working Paper No: 2797, February, Cambridge, MA.

Barlow, Robin (1994), „Population Growth and Economic Growth: Some More Correlations”, Population and Development Review, 20 (1) s. 153-165.

Bloom, E. David ve Canning, David ve Sevilla, Jaypee (2001), „Economic Growth and The Demographic Transition", NBER Working Paper Series, December, No: 8685, s.1-87.

Bloom E. David - Canning, David. ve Graham, Bryan (2003), „Longevity and Lifecycle Savings”, Scand J. Of Economics, 105(3), s.319-338.

Bloom, E. David - Canning, David - Mansfield, Rick ve Moore, Michael (2006), „Demographic Change, Social Security Systems and Savings", PGDA Working Paper No:19, Program on The Global Demography of Aging Working Paper Series, http://www.hsph.harvard.edu/pgda/working.htm.

Bloom E. David - Canning, David ve Finlay, E. Jocelyn (2008), „Population Aging and Economic Growth in Asia”, PGDA Working Papers, 4008, September, s. 1-38.

Bloom E. David - Canning, David - Fink, Günther ve Finlay, E. Jocelyn (2009), „Fertility, Female Laborforce Participation and the Economic Dividend ", Journal of Economic Growth, 14, s. 79-101.

Bloom, D.E., Canning, D. and Fink, G. (2010), „Implications of population ageing for economic growth”, Oxford Review of Economic Policy 26 (4): 583-612.

Bloom, E. David - Canning, David.- Fink, Günther (2011), „Implications of Population Aging for Economic Growth", Program on the Global Demography of Aging Working Paper Series, No: 64, January, s. 139.: 12-13.

Boersch-Supan H. Axel. - Winter, K. Joachim. (2001), „Population Aging, Savings Behavior and Capital Markets", NBER Working Paper Series, No: 8561, October, s. 1-51.

Cutler, M. David - Poterba M. James - Sheiner, M. Louise. ve Summers, H. Lawrence (1990), "An Aging Society: Opportunity or Challenge", Brookings Papers on Economic Activity, 1, s. 1-60.

Deaton, Angus ve Paxson, Christina. (2000), „Growth, Demographic Structure and National Saving in Tawian", Research Program in Development Studies, Princeton University, s. 1-46.

Dos Santos, Manon Dominguez, „Vieillissement démographique et chômage”, Revue française d'économie, 2001, Volume 16, no.1, ss.3-50.

Economic Policy Committee and European Commission, „The Impact of Ageing on Public Expenditure: Projections for the EU25 Member States on Pensions, Health Care, Long-term Health Care, Education and Unemployment Transfers", Special Report No: 1/2006-Annex, 2006.

Fogel, W. Robert (1994), „Economic Growth, Population Theory and Physiology: The Bearing of ong-Term Processes on the Making of Economic Policy", NBER Working Paper Series, No: 4638, February, s. 150 . 
IJASOS- International E-Journal of Advances in Social Sciences, Vol. IV, Issue 10, April 2018

Fougere, Maxime ve Merette, Marcel (1991), "Population Ageing and Economic Growth in Seven OECD Countries", Economic Studies and Policy Analysis Division Department of Finance, Kanada, s.411427.

Futagami, Koichi ve Nakajima, Tetsuya (2001), "Population Aging and Economic Growth”, Journal of Macroeconomics, Vol: 23, No: 1, s.31-44.

Groome, W. Todd, Nicolas Blancher, Parmeshwar Ramlogan, „Le vieillissement et les marchés financiers”, Finances \& Développement, Vol.43, no.3, Septembre 2006, ss.44-47.

Harris, Amy Rehder - Evans N. William - Schwab, M. Robert. (2001), „Education Spending in an Aging America" Journal of Public Economics, 81, ss. 449-472.

Higgins, Matthew (1998), „Demography, National Savings and International Capital Flows”, http://www.newyorkfed.org/

Hock, H. and Weil, D. N. (2012) "On the dynamics of the age structure, dependency and consumption", Journal of Population Economics, Springer, 25: 1019-1043.

Jolivet, Annie, „Vieillissment, salaire et demande des travailleurs âgées”, Travail et Emploi, no.88, Octobre 2001, ss.65-82.

Kelley, C. Allen ve Schmidt, M. Robert (1996), „Saving, Dependency and Development”, Journal of Population Economics, Vol: 9, No: 4, November, s.365-386.

Lee, Ronald - Mason, Andrew (2010), „Fertility, Human Capital end Economic Growth over the Demographic Transition", European Journal of Population, 26 (2), May, s.159-182.

Lee, S.H., Mason, A. and Park, D. (2011), „Why Does Population Aging Matter So Much for Asia Population Aging, Economic Security and Economic Growth in Asia", ERIA Discussion Paper Series, ERIA-DP2011-04.

Lefebvre, Mathieu (2006), „Population Ageing and Consumption Demand in Belgium”, CREPP-University of Liege, s.1-20.

Leibfritz, Willi - Roseveare, Deborah - Fore, Douglas ve Wurzel, Eckhard (1995), „Ageing Populations, Pension Systems and Government Budgets: How Do They Affect Saving", OECD Economics Department Working Papers, No: 156, Paris, s.1-96.

Lisenkova, K., Mérette, M. and R. Wright (2012), „The Impact of Population Ageing on the Labour Market: Evidence from Overlapping Generations Computable General Equilibrium (OLG-CGE) Model of Scotland", Discussion paper in Economic, Strathclyde, 12-13.

Narciso, A. (2010), „The impact of population ageing on international capital flows”, MPRA Paper, 26457.

Prettner, Klaus (2009), „Population Ageing and Endogenous Economic Growth”, VID Working Paper, (8), s. $1-30$.

Prettner, K. (2012), „Population aging and endogenous economic growth”, Journal of Population Economics, DOI 10.1007/s00148-012-0441-9.

Romer M. Paul (1989), „Human Capital and Growth: Theory and Evidence”, NBER Working Papers 3173, National Bureau of Economic Research, Inc, s.1-51.

Salin, Pascal, „Les prélèvements obligatoire, cause majeure du chômage”, Revue des études humaines, no.spécial, 1996, s.37.

Walder, A. B. and Döring, T., (2012), „The Effect of Population Ageing on Private Consumption - A Simulation for Austria based on Household Data up to 2050", Eurasian Economic Review, 2: 63-80.

Zweifel, Peter - Felder, Stefan.ve Werblow, Andreas (2004), „Population Ageing and Health Care Expenditure: New Evidence on the "Red Herring", The Geneva Papers on Risk and Insurance, Vol: 29, No: 4, October, s. 652-666.

Zhelezarov, I., (2009). Otsenyavane na sistemite za upravlenie na kachestvoto na visshite uchilishta. „Kachestvo na vissheto obrazovanie v Balgariya - Problemi i perspektivi 2009”. Ruse. 2009.

(Железаров, И., (2009). Оценяване на системите за управление на качеството на висшите училища. „Качество на висшето образование в България - Проблеми и перспективи 2009”. Pyce. 2009). 
IJASOS- International E-Journal of Advances in Social Sciences, Vol. IV, Issue 10, April 2018

Zhelezarov, I., (2005). Sistema za izmervane i upravlenie na kachestvoto na obuchenie vav visshite tehnicheski uchilishta. Avtoreferat na disertatsiya za poluchavane na obrazovatelna i nauchna stepen „Doktor”. (Железаров, И., (2005). Система за измерване и управление на качеството на обучение във висшите технически училища. Автореферат на дисертация за получаване на образователна и научна степен „Доктор”).

Ivanov, I., I. Zhelezarov. (1998) Otnosno kachestvoto na uchebniyat protses vav visshite uchebni zavedeniya. Yubileyna nauchna sesiya s mezhdunarodno uchastie -120 godini ot sazdavaneto na VVOVU „Vasil Levski”, Veliko Tarnovo. (Иванов, И., И. Железаров. (1998) Относно качеството на учебният процес във висшите учебни заведения. Юбилейна научна сесия с международно участие - 120 години от създаването на ВВОВУ „Васил Левски”, Велико Търново). 